Btażej Lepczyński

Zaakceptowany: 03.04.2020

Eugeniusz Gostomski

Uniwersytet Gdański

\title{
Metodyczne i rynkowe aspekty ratingu listów zastawnych - doświadczenia z rynku niemieckiego
}

\author{
METHODOLOGICAL AND MARKET ASPECTS OF \\ COVERED BOND RATING - EXPERIENCE FROM THE \\ GERMAN MARKET
}

\begin{abstract}
Rating międzynarodowych agencji ratingowych odgrywa szczególnq rolę na rynku listów zastawnych. Z uwagi bowiem na duży stopień skomplikowania emisji listów zastawnych $w$ zdecydowanej większości przypadków emisje listów zastawnych maja rating przyznany przez przynajmniej jednq międzynarodowq agencje ratingowq. Oznacza to, że rating stanowi ważna determinante rozwoju rynku listów zastawnych. Nasze badania $w$ odniesieniu do rynku niemieckiego potwierdzaja teze o dużym znaczeniu ratingu $w$ rozwoju rynku listów zastawnych. $W$ aspekcie metodycznym rating listów zastawnych jest kombinacja elementów ilościowych, jakościowych, a na końcowy wynik procedury ratingowej wplyw ma wynik oceny standingu finansowego emitenta listów zastawnych oraz jakości puli aktywów zabezpieczajacych. $Z$ przeprowadzonych badań wynika, że poziom ocen ratingowych niemieckich listów zastawnych jest wysoki i co równie ważne stabilny w czasie. Jednak pomimo wysokiego bezpieczeństwa listów zastawnych rating poszczególnym emisjom jest często nadawany przez dwie lub trzy agencje, co przesqdza o dużym znaczeniu ratingu jako czynnika rozwojowego, przede wszystkim wspierajqcego wiarygodność i przejrzystość rynku.
\end{abstract}

Słowa kluczowe: listy zastawne, rating, analiza rynku.

JEL Codes: G21, G23, G24.

\section{Wprowadzenie}

Listy zastawne są znaną od ponad 200 lat kategorią papierów wartościowych, odgrywającą ważną rolę $\mathrm{w}$ refinansowaniu portfeli wierzytelności hipotecznych. Obecnie listy zastawne są emitowane w kilkunastu krajach na świecie, ale ciagle najbardziej rozpowszechnione są w Niemczech, kolebce listów zastawnych. Należy podkreślić, że w całej historii listów zastawnych w Niemczech nie zdarzyło się ani razu, by jakikolwiek list wyemitowany w tym kraju wraz z odsetkami nie został wykupiony ${ }^{1}$. Ten fakt podkreśla wysokie bezpieczeństwo inwestowania $w$ tego typu walory finansowe. W takiej sytuacji mogłoby się wydawać, że rating międzynarodowych

\footnotetext{
${ }^{1}$ M. Sprangler, R. Werner, German Covered Bonds. Overview and Risk Analysis of Pfandbriefe, Springer, 2014, s. 1 .
} 
agencji ratingowych jest w przypadku listów zastawnych zbędny. Tak jednak nie jest. Agencje ratingowe odgrywają istotną rolę $\mathrm{w}$ ocenie jakości i wiarygodności emitowanych listów zastawnych. Praktycznie nie występują na rynkach kapitałowych emisje listów zastawnych, które nie miałyby ratingu nadanego przez jedną $\mathrm{z}$ międzynarodowych agencji ratingowych.

Celem badań była ocena znaczenia ratingu jako narzędzia oceny i jego roli w rozwoju niemieckiego rynku listów zastawnych. W artykule przedstawiono metodykę ratingu listów zastawnych Moody's oraz ocenę przyjętych założeń metodycznych. Wybór metodyki Moody's był podyktowany bardzo dużym znaczeniem ocen tej agencji na niemieckim rynku listów zastawnych. Oceniając aspekty rynkowe w badaniu, uwzględniono m.in. rolę poszczególnych agencji ratingowych w ocenie niemieckich listów zastawnych oraz poziom i stabilność ocen ratingowych w latach 2015-2018.

\section{Przegląd literatury}

List zastawny to dłużny papier wartościowy, imienny lub na okaziciela, który w Niemczech może być emitowany przez bank hipoteczny lub od 2005 r. przez inny uprawniony do tego bank, przy czym podstawą emisji są wierzytelności bankowe z tytułu udzielonych kredytów, zabezpieczone hipoteką lub w inny sposób określony przez prawo. Ich historia liczy 250 lat - pierwsze listy zastawne w Prusach zostały wyemitowane z inicjatywy króla Fryderyka Wielkiego w 1769 roku$^{2}$. List może przybrać postać materialną, ale najczęściej występuje w formie zdematerializowanej. W Niemczech istnieją cztery rodzaje listów zastawnych:

- hipoteczne listy zastawne, które służą do refinansowania kredytów hipotecznych na zakup lub wybudowanie nieruchomości mieszkaniowych lub komercyjnej i są zabezpieczone (pokryte) należnościami z tytułu tych kredytów;

- publiczne list zastawne, które pokryte są należnościami z tytułu kredytów udzielonych podmiotom państwowym bądź innym jednostkom publicznym lub należnościami $\mathrm{z}$ tytułu innych kredytów zabezpieczonych gwarancjami państwa lub samorządu terytorialnego;

- okrętowe listy zastawne refinansujące kredyty na zakup statków i zabezpieczone hipoteką na odpowiednim statku;

- samolotowe listy zastawne, które przeznaczone są na refinansowanie udzielanych przez banki kredytów na zakup samolotów ${ }^{3}$.

Jak w przypadku każdego dłużnego papieru wartościowego, listy zastawne wymagają obiektywnej oceny ryzyka ewentualnego zaprzestania płatności wynikających z papieru wartościowego na rzecz inwestora. Listy zastawne zalicza się do bezpiecznych papierów wartościowych m.in. z uwagi na tzw. podwójny mechanizm ochrony, który jest oparty na standingu emitenta listów zastawnych i na zabezpieczeniu na odpowiednich aktywach ${ }^{4}$. W kształtowaniu bezpieczeństwa listów zastawnych

\footnotetext{
${ }^{2}$ S. L. Schwarcz, The Conundrum of Covered Bonds, The Business Lawyer, Vol. 66, 2011, s. 563-564.

${ }^{3}$ Pfandbrief-Arten,

https://www.pfandbrief.de/site/de/vdp/pfandbrief/pfandbrief_emissionen/pfandbrief_arten.html (14.07.2019).

${ }^{4}$ A. Vucetich, A. Watson, 2013, Discovering covered bonds - the market, the challenges, and the Reserve Bank's response, Reserve Bank of New Zealand: Bulletin, Vol. 76, No. 2, 2013, s. 17.
} 
szczególną rolę odgrywają zapisy ustawowe dotyczące ochrony inwestorów w przypadku bankructwa instytucji finansowej emitującej listy zastawne, ograniczające wartość pozostających w obiegu listów zastawnych poprzez odniesienie do posiadanych funduszy własnych, czy możliwości refinansowania za pomocą listów zastawnych kredytów hipotecznych. Te elementy decydują o bardzo wysokim poziomie ocen ratingowych listów zastawnych. Pojawia się zatem pytanie, czy w przypadku listów zastawnych rating jest w ogóle potrzebny ${ }^{5}$. Wskazuje się, że rating zyskuje na znaczeniu wraz z rosnącą heterogenicznością sektora bankowości hipotecznej. Związane jest to m.in. z faktem liberalizacji zasad emisji listów zastawnych i stworzenia możliwości emitowania tego typu instrumentów finansowych również bankom uniwersalnym. Co więcej, kwestie związane z wiarygodnością emitentów listów zastawnych stają się coraz ważniejsze dla inwestorów ${ }^{6}$, „Rating stanowi syntetyczny miernik relatywnej jakości kredytowej, przyczyniając się do obiektywizacji inwestycji (...),7.

Istotnym czynnikiem, który wpłynął na zróżnicowanie ratingu listów zastawnych był globalny kryzys finansowy. „Historycznie, szczególnie przed kryzysem, większość listów zastawnych miała rating AAA" . Po kryzysie nastapił spadek ocen ratingowych, głównie za sprawą włoskich i hiszpańskich listów zastawnych ${ }^{9}$. W Niemczech inwestorzy doceniają ograniczające ryzyko w listach zastawnych, ale nie traktują ich już w kategoriach substytutu obligacji rządowych (Kronenberg S., 2013, s. 707).

W przypadku listów zastawnych na pierwszym planie należy umieścić rolę agencji ratingowej jako instytucji potwierdzającej wysoką jakość listów zastawnych. Rola agencji ratingowych wzrasta również wraz z umiędzynarodowianiem się rynków listów zastawnych. To właśnie w wymiarze międzynarodowym rating nadawany przez agencje ratingowe jest najbardziej przydatny i w istotnym stopniu minimalizuje koszty pozyskiwania informacji.

Trzeba również pamiętać, że emisje listów zastawnych są często skomplikowanymi strukturami i choćby $\mathrm{z}$ tego względu wymagają zewnętrznej oceny ich standingu finansowego. Podkreśla się, że rating jest potrzebny w celu zbadania podstawowej jakości aktywów zabezpieczających listy zastawne oraz pokazania sytuacji finansowej banku emitenta ${ }^{10}$. Wspomniana wyżej podwójna ochrona jako cecha charakterystyczna listu zastawnego wprowadza do analizy dość wyjątkową kombinację kryteriów $\mathrm{w}$ analizie ratingowej, związaną $\mathrm{z}$ jednej strony bezpośrednio $\mathrm{z}$ wiarygodnością finansową banku emitującego listy zastawne, z drugiej zaś odzwierciedlającą zdolność puli zabezpieczeń do pełnej i terminowej spłaty odsetek oraz kwoty głównej w przypadku wystąpienia scenariusza niewypłacalności emitenta ${ }^{11}$. Kolejnym

\footnotetext{
${ }^{5}$ H. Scholz, Bedeutung des Ratings für die Emission von Pfandbriefen [w:] H. E. Büschgen, O. Everling, Handbuch Rating, Gabler, 1996, s. 469.

${ }^{6}$ Der deutsche Pfandbriefmarkt 2017/2018, Deutsche Pfandbriefe im Trend der Zeit, Eine Fachthemenreihe der DZ HYP, 2017, s. 16.

${ }^{7}$ A. Dżuryk, List zastawny a stabilność polskiego system finansowego, Publikacja Europejskiego Kongresu Finansowego, Sopot, 2017, s. 14.

${ }^{8}$ Kemmisch R., Wilkinson Ch., Covered Bonds in the European Union: Harmonisation of legal frameworks and market behaviours. Final report, European Commission, 2017, s. 37.

${ }^{9}$ Tamże.

${ }^{10}$ R. Monro-Davis, Die Bonitätsbewertung von Banken, [w:] H. E. Büschgen, O. Everling, Handbuch Rating, Gabler, 1996, s. 216.

${ }^{11}$ Y. Foster, V. Purwin, Covered Bond Rating, 2011.
} 
elementem specyficznym, jeśli chodzi o rating listów zastawnych, jest kombinacja czynników o charakterze ekonomicznym i prawnym. Te ostatnie często decydują w przypadku listów zastawnych o podwyższeniu ich ratingu ponad rating emitenta.

\section{Material i metodyka badań}

$\mathrm{W}$ celu przedstawienia metodycznych aspektów związanych $\mathrm{z}$ podejściem agencji ratingowych do ratingu listów zastawnych wykorzystano metodykę międzynarodowej agencji ratingowej Moody's. Podejście stosowane przez Moody's można traktować $\mathrm{w}$ kategoriach wiodącego $\mathrm{z}$ uwagi na kluczową rolę tej agencji $\mathrm{w}$ ocenie listów zastawnych w Europie (w tym w Niemczech).

Analizie i ocenie podlegały kryteria ilościowe i jakościowe stosowane przez Moody's, konstrukcja oceny oraz zależności pomiędzy ratingiem listów zastawnych i ratingiem kraju (suwerena). Analiza nie ograniczała się tylko do przedstawienia metodyki ratingowej, ale również polegała na ocenie przyjętych założeń i zastosowanego przez Moody's podejścia. Badaniu podlegały również postkryzysowe zmiany w metodyce ratingowej, związane $\mathrm{m}$.in. $\mathrm{z}$ wyłączeniem listów zastawnych $\mathrm{z}$ bailin w ramach dyrektywy BRRD.

Drugim obszarem badawczym była ocena roli ratingu na niemieckim rynku listów zastawnych. Wybór rynku do badań nie był przypadkowy, ponieważ rynek niemiecki to historycznie najstarszy i obecnie największy rynek listów zastawnych $\mathrm{z}$ dużą rolą w przeszłości publicznych listów zastawnych. Badania miały pozwolić odpowiedzieć na pytania dotyczące stopnia pokrycia ratingiem emisji listów zastawnych w Niemczech, rozkładu w zakresie poziomu nadawanych ocen ratingowych oraz skali ratingów podwójnych i potrójnych. Ocenie podlegała również stabilność ratingów niemieckich listów zastawnych $\mathrm{w}$ czasie. Podstawowym materiałem badawczym były raporty cykliczne DZ Hypo Banku oraz materiały analityczne Moody’s.

\section{Metodyczne aspekty ratingu listów zastawnych na przykładzie Moody's}

Każda globalna agencja ratingowa $\mathrm{w}$ procesie nadawania ratingu listom zastawnym przywiązuje dużą wagę do oceny prawdopodobieństwa niewykonania przez emitenta zobowiązań wobec ich posiadacza, czyli spłaty wartości nominalnej listów zastawnych wraz z odsetkami. W ogólnym zarysie proces nadawania ratingu polega na ocenie poziomu ochrony nabywcy listów zastawnych, wiarygodności kredytowej emitenta, jakości kredytów hipotecznych oraz wszystkich istotnych mechanizmów wzmacniających jakość emisji. Duże znaczenie ma również rating kraju.

Agencje ratingowe zwracają też uwagę na to, czy w banku emitującym listy zastawne przestrzegana jest zasada kongruencji (zgodności) finansowania. Oceniają więc, czy istnieje zgodność terminów wymagalności wyemitowanych listów zastawnych i zapadalności kredytów hipotecznych - należności z tytułu tych kredytów zabezpieczone hipoteką stanowią pokrycie spłaty będących w obiegu listów. Kongruencja dotyczy też rodzaju oprocentowania czy waluty. Jeżeli takiej zgodności brak, to na rating ocenianych listów zastawnych duży wpływ ma rating ich emitenta (banku).

Metodyki ratingowe listów zastawnych uległy istotnym zmianom, na co wpływ miała dyrektywa BRRD z 2014 r. dotycząca ram uporządkowanej restrukturyzacji 
i likwidacji banków, która wyłączyła listy zastawne z mechanizmu bail-in (umorzenia lub konwersji długu) ${ }^{12}$. Modyfikacje w zakresie metodyki nadawania ratingu, które zostały wprowadzone przez wiodące agencje ratingowe wskazują na wzrost stopnia uniezależnienia ratingu listów zastawnych od ratingu emitenta. Taki kierunek zmian potwierdza przedstawiona poniżej metodyka nadawania ratingu listom zastawnym stosowana przez Moody's.

Spośród największych agencji ratingowych na świecie za specjalistę w zakresie ratingu listów zastawnych uznaje się agencję Moody's. Pod koniec 2016 roku ratingiem od Moody's dysponowało prawie 250 programów listów zastawnych, z których $60 \%$ uzyskało rating Aaa, $21 \%$ rating Aa i $10 \%$ rating $\mathrm{A}^{13}$. Gorszy rating miały jedynie listy zastawne emitowane w peryferyjnych krajach europejskich o niskim standingu.

Metodyka nadawania ratingu listom zastawnym przez agencję Moody's, obejmuje dwa etapy: ilościowy i jakościowy ${ }^{14}$. Etap ilościowy opiera się na modelu oczekiwanej straty (EL), definiowanej w następujący sposób ${ }^{15}$ :

$E L=\sum_{i=1}^{n} P_{i} * L_{i} * d f_{i}$

gdzie:

i - liczba okresów do ostatecznego terminu zapadalności n

$\mathrm{P}_{\mathrm{i}}$ - prawdopodobieństwo bankructwa banku w okresie $\mathrm{i}$

$\mathrm{L}_{\mathrm{i}}$ - strata $\mathrm{z}$ tytułu niewykonania zobowiązania w okresie $\mathrm{i}$

$\mathrm{df}_{\mathrm{i}}-$ współczynnik dyskonta dla okresu $\mathrm{t}_{0}-\mathrm{t}_{\mathrm{i}}$.

Przyjęte podejście pozwala na oszacowanie wielkości oczekiwanej straty w razie upadłości emitenta, tzn. określenie na bazie standingu emitenta prawdopodobieństwa jego bankructwa i wysokości związanej z tym straty na masie aktywów stanowiących zabezpieczenie (pokrycie) wyemitowanych listów zastawnych. W zależności od tego, jak duża będzie ta strata, Moody's, nadaje danym listom zastawnym rating, który jest rozumiany jako maksymalny rating możliwy do uzyskania przez te listy ${ }^{16}$.

Drugi etap nadawania oceny ratingowej emitentom listów zastawnych ma charakter jakościowy. Kluczowe znaczenie w przypadku metodyki stosowanej przez Moody's ma tzw. wskaźnik terminowej płatności TPI (Timely Payment Indicator). „TPI jest oceną prawdopodobieństwa, że posiadacz listu zastawnego uzyska terminowo wszystkie płatności po niewypłacalności banku-sponsora"17. Zgodnie $\mathrm{z}$ obowiązującymi regulacjami prawnymi prawie we wszystkich krajach upadłość emitenta listów zastawnych nie pociąga za sobą natychmiastowego postawienia listów w stan wymagalności, a więc ich wykupu przez upływem terminu ich ważności. Czynniki jakościowe uwzględnione we wskaźniku TPI korygują in minus ocenę ilościową.

Dwuetapowy proces oceny wyznaczania ratingu listów zastawnych przez Moody's poprzedzony jest ustaleniem tzw. kotwicy (CB Anchor) w oparciu o ocenę ryzyka

\footnotetext{
${ }^{12}$ A. Dżuryk, op. cit., s. 131 i 136.

${ }^{13}$ Covered Bonds - Ratingmethoden erklärt: Moody's, 2017, Research-Publikation der DZ Bank AG, s. 3.

${ }^{14}$ Moody's Approach to Rating Covered Bonds, Moody’s Investors Service, 2019, s. 1.

${ }^{15}$ Y. Forster, V. Purwin, op. cit., s. 7-7 i 7-8.

${ }^{16}$ Covered..., 2017, op. cit., s. 7.

${ }^{17}$ Y. Forster, V. Purwin, op. cit., s. 7-8
} 
kontrahenta (Counterparty Risk Assesment) ${ }^{18}$. Ta ocena stanowi punkt wyjścia dla ustalenia ratingu listów zastawnych. Wyznaczony $w$ oparciu o model EL maksymalny rating może ulec obniżeniu w drugim etapie procedury ratingowej, w wyniku uwzględnienia w ocenie listów zastawnych czynników jakościowych, odzwierciedlonych w indeksie TPI oraz wzięcia pod uwagę ratingu kraju emitenta ${ }^{19}$.

Wskazana wyżej kotwica opiera się na sile kredytowej emitenta listów zastawnych, która będzie miała najistotniejszy wpływ na wyniki programu emisji listów zastawnych przed niewykonaniem zobowiązania przez emitenta ${ }^{20}$. W tym sensie kotwica ,jest miarą ryzyka, że emitent przestanie wykonywać zobowiązania z tytułu listów zastawnych"21.

Wielkość straty w przypadku upadłości emitenta w oparciu o model EL określa się jako różnicę między wartością nominalnej masy pokrycia a przyjętą wartością pokrycia w założonym stress teście ${ }^{22}$. Na wysokość oczekiwanej straty wpływ mają dwa podstawowe rodzaje ryzyka: ryzyko kredytowe i rynkowe ${ }^{23}$. To ostatnie obejmuje: ryzyko refinansowania i ryzyko zmiany stopy procentowej, a przy kredytach w obcej walucie jeszcze ryzyko kursowe ${ }^{24}$.

Opis procedury ratingowej rozpoczynamy od ryzyka kredytowego, które w kontekście listów zastawnych, najogólniej ujmując, zależy od jakości wchodzących w skład masy pokrywanych papierów wartościowych wierzytelności hipotecznych lub aktywów poręczonych przez instytucje publiczne. W określaniu jakości aktywów Moody's wykorzystuje tzw. miernik ryzyka zabezpieczeń (collateral score). Zgodnie z przyjętą metodyką ${ }^{25}$ miernik ryzyka zabezpieczeń interpretuje się w ten sposób, że im wyższa jest jakość kredytowa puli zabezpieczeń, tym jest on niższy. Wskaźnik ten pokazuje liczoną w procentach wysokość strat w przypadku bankructwa emitenta, wynikającą $\mathrm{z}$ utraty części należności $\mathrm{z}$ tytułu kredytów zabezpieczających listy ${ }^{26}$. Collateral score oblicza się indywidualnie dla każdej masy pokrycia, czyli dla poszczególnych rodzajów zabezpieczenia listów zastawnych, a więc kredytów na finansowanie mieszkań prywatnych, kredytów zaciągniętych na budowę obiektów komercyjnych czy kredytów dla podmiotów prawa publicznego ${ }^{27}$.

Kolejnym rodzajem ryzyka uwzględnianym przez Moody's w analizie jest ryzyko refinansowania, które należy utożsamiać $\mathrm{z}$ ryzykiem strat $\mathrm{z}$ tytułu niezgodności $(\text { mismatch })^{28}$. Moody's tym samym nawiązuje do jednego $\mathrm{z}$ głównych problemów występujących przy emisji listów zastawnych, a mianowicie ryzyka niedopasowania. Rzadko bowiem zdarza się, żeby termin spłaty kredytów hipotecznych stanowiących zabezpieczenie listów zastawnych pokrywał się z terminem wykupu listów zastawnych. $\mathrm{Z}$ tego braku zgodności (braku kongruencji) między terminem wymagalności listów

\footnotetext{
${ }^{18}$ Moody's..., op. cit, s. 4.

${ }^{19}$ Covered..., 2017, op. cit., s. 7.

${ }^{20}$ J. Soldera, J. P. Soriano, N. Lindstrom, Rating agencies and methodology. Moody's [w:] ECBC European Covered Bond Fact Book 2019, EMF/ECBC, 2019, s. 568.

${ }^{21}$ Tamże.

${ }^{22}$ Covered..., 2017, op. cit., s. 8.

${ }^{23}$ Tamże.

${ }^{24}$ Tamże.

${ }^{25}$ Moody's..., op. cit., s. 5-6.

${ }^{26}$ Covered..., 2017, op. cit., s. 8.

${ }^{27}$ Tamże.

${ }^{28}$ Moody's..., op. cit., s. 6.
} 
zastawnych i terminem zapadalności zabezpieczających je aktywów (kredytów hipotecznych) wynika omawiane ryzyko refinansowania ${ }^{29}$. W takiej sytuacji w razie upadłości emitenta środki z naturalnej amortyzacji masy pokrycia listów zastawnych mogą nie wystarczyć na wykup w terminie wszystkich listów podlegających umorzeniu $^{30}$. Aby więc zagwarantować wierzycielom terminowe płatności $\mathrm{z}$ tytułu listów zastawnych, ich emitent oprócz strumieni pieniężnych z tytułu spłaty kredytów zabezpieczających listy musi mieć dostęp do dodatkowych środków płynnych, np. pochodzących ze sprzedaży określonego majątku lub z pożyczki od innego banku.

Według Moody's ryzyko refinansowania zależy od trzech czynników ${ }^{31}$ :

1. tzw. marży refinansowania, która jest tym wyższa, im gorsza jest jakość portfela kredytowego;

2. wielkości tej części masy pokrycia, która z powodu braku zgodności terminów zapadalności listów zastawnych i wymagalności zabezpieczających je kredytów hipotecznych nie może być wykorzystana w danym okresie jako źródło pieniędzy na umorzenie listów zastawnych i w związku z tym konieczne jest przejściowe finansowanie $\mathrm{z}$ innych źródeł;

3. długości przeciętnego okresu występowania ryzyka refinansowania, przez który trzeba zapewnić dodatkowe finansowanie.

Łącznie te trzy komponenty określają wysokość ryzyka refinansowania. Im są one większe, tym wyższe jest ryzyko refinansowania.

Moody's przywiązuje dużą wagę także do ryzyka kursowego i ryzyka stopy procentowej wynikającego $\mathrm{z}$ braku zgodności między oprocentowaniem aktywów stanowiących pokrycie listów zastawnych i oprocentowaniem niewykupionych jeszcze listów. Zmiany stóp procentowych lub kursów walutowych mogą powiem spowodować, że strumienie pieniężne $\mathrm{z}$ walorów pokrycia nie wystarczą na płatności związane z listami zastawnymi (odsetki i zwrot kapitału). Do oceny zarówno ryzyka stopy procentowej jak i ryzyka walutowego wykorzystuje się testy i rachunek symulacyjny ${ }^{32}$

Kończąc charakterystykę elementu ilościowego warto zwrócić uwagę na czynniki zmniejszające oczekiwane straty w modelu EL. Zalicza się do nich ${ }^{33}$ :

1. nadzabezpieczenie (ustawowe lub dobrowolne) listów zastawnych, którą stanowi część masy pokrycia przewyższająca wartość listów zastawnych;

2. transakcje swapowe zawarte $w$ celu zabezpieczenia się przed ryzykiem rynkowym;

3. dysponowanie odpowiednią rezerwą płynności;

4. dopuszczalność przesunięcia w czasie terminu wykupu.

$\mathrm{Na}$ rating listów zastawnych wpływ ma również standing państwa - siedziby emitenta. Pośrednio wpływa on poprzez występowanie $\mathrm{w}$ masie pokrycia wyemitowanych listów kredytów dla instytucji państwowych oraz uwzględnianie $\mathrm{w}$ ocenie ryzyka refinansowania $\mathrm{i}$ przy konstruowaniu indeksu TPI kondycji ekonomicznej państwa ${ }^{34}$. Natomiast bezpośredni wpływ standingu państwa na rating

\footnotetext{
${ }^{29}$ Covered..., 2017, op. cit., s. 12.

${ }^{30}$ Tamże, s. 10.

${ }^{31}$ Moody's..., op. cit., s. 6-7.

${ }^{32}$ Szerzej: Moody's..., op. cit., s. 34-36.

${ }^{33}$ Covered..., 2017, op. cit., s. 14-16.

${ }^{34}$ Tamże, s. 21.
} 
listów zastawnych znajduje wyraz $\mathrm{w}$ tym, że specyficzne dla danego kraju ryzyka: polityczne, prawne, braku stabilizacji, wyznaczaja górny poziom ratingu, np. jeżeli kotwica ma rating A2, a TPI kategorię ,probable”, to możliwy do uzyskania rating będzie na poziomie $\mathrm{Aaa}^{35}$. Jednakże, gdy emitent będzie miał siedzibę w kraju o niższym ratingu, np. Aa2, to najwyższy rating listów zastawnych będzie też na poziomie $\mathrm{Aa}^{36}$.

Oddzielnym elementem oceny listów zastawnych przez Moody's są czynniki jakościowe. W tej fazie oceny Moody's określa za pomocą wspomnianego wcześniej indeksu TPI prawdopodobieństwo tego, że po upadłości emitenta listów zastawnych płatności na rzecz ich właścicieli będą realizowane terminowo ${ }^{37}$. Zakłada się przy tym, że środki na ten cel będa generowane przez spłatę kredytów tworzących masę pokrycia listów lub będa pochodzić od osób trzecich. Kombinacja indeksu TPI z poziomem kotwicy pozwala agencji Moody's określić najwyższy rating, jaki może być przyznany listom zastawnym. Innymi słowy, tą drogą można określić, o ile stopni rating listów może być wyższy od poziomu kotwicy ${ }^{38}$. Im wyższy będzie indeks TPI, tym bardziej rating listów będzie odbiegał in plus od standingu emitenta.

Moody's określa poziom indeksu TPI w dwóch krokach: najpierw bierze się pod uwagę aspekty prawne (czynniki systemowe) specyficzne dla listów zastawnych (szczególnie te, które zmniejszają ryzyko refinansowania), a następnie uwzględnia się czynniki charakterystyczne dla danego programu emisji listów zastawnych. Moody's zwraca uwage na pięć czynników w największym stopniu wpływających na indeks $\mathrm{TPI}^{39}$. Sa to: ryzyko refinansowania, rozwiązania prawne upoważniające zarządzającego masą pokrycia do sprzedaży części zabezpieczeń lub pozyskania dodatkowych środków na płatności z tytułu listów zastawnych, możliwość uzyskania wsparcia finansowego ze strony państwa $\mathrm{w}$ razie zagrożenia utraty płynności przez emitenta listów; transakcje zabezpieczające (hedging) oraz rodzaj masy pokrycia ${ }^{40}$.

Końcowy rating listów zastawnych to niższy wynik wynikający z modelu ilościowego EL oraz maksymalnego ratingu wynikającego $\mathrm{z} \mathrm{TPI}^{41}$. Pomimo sformalizowanego postępowania przy nadawaniu oceny ratingowej listom zastawnym, istotną rolę odgrywa także element ekspercki, ponieważ ocenę może skorygować komitet ratingowy.

Dokonując oceny przedstawionej w zarysie metodyki ratingowej Moody's w zakresie listów zastawnych, należałoby podkreślić, że kładzie się w niej duży nacisk na ocenę ilościową w kategoriach oczekiwanej straty. Tego typu podejście odróżnia metodykę Moody's od podejścia Fitch i Standard\&Poor's. W przeciwieństwie do innych międzynarodowych agencji ratingowych, Moody's koncentruje się również w większym stopniu na ocenie wiarygodności kredytowej emitenta listów zastawnych ${ }^{42}$.

\footnotetext{
${ }^{35}$ Tamże.

${ }^{36}$ Tamże.

${ }^{37}$ Moody's..., op. cit., s. 8 .

${ }^{38}$ Covered..., 2017, op. cit., s. 17.

${ }^{39}$ Tamże, s. 16.

${ }^{40}$ Tamże, s. 19.

${ }^{41}$ J. Soldera, J. P. Soriano, N. Lindstrom, Rating agencies and methodology. Moody's [w:] ECBC European Covered Bond Fact Book 2018, EMF/ECBC, 2018, s. 547.

${ }^{42}$ M. Melms, Vergleichende Darstellung der Ratingansätze für Pfandbriefe, 2012, Norddeutsche Landesbank [w:] Der Pfandbrief 2012/2013, Verband deutscher Pfandbriefbanken, http://doczz.com.br/doc/1202195/derpfandbrief-2012---2013---verband-deutscher-pfandbrief...[dostęp: 10.01.2018]., s. 71.
} 
Pozytywnie w procedurze Moody's należy ocenić praktykę oddzielenia aspektów ilościowych od aspektów jakościowych oraz uwzględnianie indeksu TPI, który nie pozwala nadać wysokiego ratingu emitentowi o słabym standingu tylko dzięki nadmiernemu pokryciu wyemitowanych listów ${ }^{43}$. Kolejne ważne cechy metodyki Moody's, które są warte podkreślenia, to łączenie elementów ilościowych z jakościowymi oraz kompleksowość metodyki. Trzeba jednak pamiętać, że wraz z większym stopniem skomplikowania wzrasta ryzyko powielania niektórych elementów oceny. Powstaje zatem efekt niezamierzonego nadawania zbyt dużego znaczenia niektórym kryteriom. Relatywnie duży stopień skomplikowania powoduje również, że sposób nadawania ratingu staje się zrozumiały $\mathrm{w}$ zasadzie tylko dla inwestorów profesjonalnych. Przyjęte założenia metodyczne wskazuja, że na końcową ocenę wpływ ma standing emitenta i jakość aktywów/kredytów hipotecznych oraz zabezpieczenia prawne.

\section{Rola ratingu na niemieckim rynku listów zastawnych}

W Niemczech największe znaczenie mają hipoteczne lisy zastawne. W 2005 roku przestała obowiazywać w Niemczech zasada, że prawo do emisji listów zastawnych mają tylko banki specjalne (hipoteczne, okrętowe oraz banki krajów związkowych).

Zgodnie z nowymi regulacjami ustawowymi listy zastawne mogą emitować także banki uniwersalne, które uzyskały odpowiednią licencję od władz nadzoru bankowego. Aby otrzymać w Niemczech licencję na emisję określonego rodzaju listów zastawnych (hipotecznych, publicznych, okrętowych lub samolotowych listów zastawnych), bank musi spełnić następujące warunki ${ }^{44}$ :

1) posiadać podstawowy kapitał własny nie mniejszy niż o wartości $25 \mathrm{mln}$ euro;

2) mieć zamiar prowadzić biznes związany $\mathrm{z}$ listami zastawnymi w sposób regularny i trwały;

3) dysponować własnymi regulacjami i instrumentami zarządzania ryzykiem związanym z masą aktywów stanowiących pokrycie wyemitowanych listów zastawnych i z samą emisją;

4) dysponować odpowiednią strukturą organizacyjną i wyposażeniem banku.

$\mathrm{W}$ trosce o wysokie bezpieczeństwo inwestowania w listy zastawne, ich emitenci i masa pokrycia stanowiąca zabezpieczenie wyemitowanych listów podlegają szczególnym procedurom nadzorczym ze strony władz nadzorczych (BaFin).

W 2018 r. w Niemczech na rynku listów zastawnych było aktywnych 77 banków, ale liczba banków dysponujących licencją na emisję listów była większa. Większość tych banków zrzeszonych jest $\mathrm{w}$ Verband deutscher Pfandbriefbanken (vdp). Rynek emitentów listów zastawnych cechuje się wysoką koncentracją - 10 największych banków pod względem wolumenu będących w obiegu listów zastawnych ma $65 \%$ udziału w rynku ${ }^{4}$. Najsilniejszą grupę tworzą banki hipoteczne ( $42 \%$ udziału w rynku) na czele z Calenberger Kreditverein w Hanowerze, następnie banki krajów związkowych

\footnotetext{
${ }^{43}$ Covered..., 2017, op. cit., s. 22.

${ }^{44}$ J. Tolckmitt, O. Stôcker, Die rechtlichen Grundlagen der Pfandbriefemissionen, Der Pfandbrief 2017/2018, vdp, Berlin, 2017, s. 8.

${ }^{45}$ Der deutsche Pfandbriefmarkt 2018/2019. Deutsche Pfandbriefe unter Einfluss Europas, Eine Fachthemenreihe der DZ HYP, 2018, s. 7.
} 
(28\%), banki komercyjne (22\%) i banki z sektora kas oszczędnościowych $(8 \%)^{46}$. Banki emitujące listy zastawne udzielają kredytów na budowę i zakup nieruchomości mieszkaniowych, komercyjnych (głównie budynki biurowe i centra handlowe) oraz na sfinansowanie wydatków państwa i jednostek samorządu terytorialnego.

Wartość nowych emisji listów zastawnych w Niemczech od kilkunastu lat się zmniejsza. W największym stopniu dotyczy to publicznych listów zastawnych, których emisja zmalała z poziomu 152 mld euro w 2003 roku do 7 mld euro w 2018 r., co głównie wynika z ograniczania wydatków publicznych. W przypadku listów hipotecznych spadek wartości nowych emisji nie był tak drastyczny, a w 2015 r. i 2018 r. nawet odnotowano wzrost wartości nowych emisji. Większość listów zastawnych emitowana jest na rynku publicznym - w 2017 r. aż $65 \%$ wolumenu nowych emisji. Niemieckie listy zastawne są papierami długookresowymi o stałym oprocentowaniu, które od wielu lat jest niższe niż $1 \%$. Jednocześnie zmniejsza się wolumen listów zastawnych pozostających w obiegu, również głównie publicznych listów zastawnych (zob. tab. 1).

Przy utrzymującej się relatywnie wysokiej liczbie nowych emisji hipotecznych listów zastawnych zmieniła się w Niemczech struktura rynku. O ile bowiem na koniec 2000 r. hipoteczne listy zastawne stanowiły 22 proc. wolumenu wszystkich listów zastawnych w obrocie, to w 2018 r. zajmowały już dominującą pozycję w wolumenie (64 proc.). Spadek znaczenia publicznych listów zastawnych można powiązać z prowadzoną w Niemczech konserwatywną polityką budżetową oraz ich niską atrakcyjnością inwestycyjną.

Tabela 1. Rynek listów zastawnych w Niemczech (w mld euro) w latach 2000-2018

\begin{tabular}{|c|c|c|c|c|}
\hline \multirow{2}{*}{ Rok } & \multicolumn{2}{|c|}{ Listy zastawne w obrocie } & \multicolumn{2}{|c|}{ Nowe emisje } \\
\cline { 2 - 5 } & Publiczne & Hipoteczne i pozostałe & Publiczne & Hipoteczne i pozostałe \\
\hline 2000 & 859 & 247 & 105 & 50 \\
2001 & 849 & 256 & 130 & 44 \\
2002 & 827 & 261 & 140 & 52 \\
2003 & 797 & 256 & 152 & 60 \\
2004 & 760 & 250 & 132 & 32 \\
2005 & 735 & 238 & 141 & 35 \\
2006 & 721 & 228 & 108 & 27 \\
2007 & 678 & 206 & 90 & 63 \\
2008 & 579 & 227 & 52 & 58 \\
2009 & 486 & 225 & 42 & 45 \\
2010 & 412 & 228 & 31 & 42 \\
2011 & 356 & 230 & 14 & 32 \\
2012 & 301 & 224 & 16 & 34 \\
2013 & 246 & 206 & 15 & 31 \\
2014 & 207 & 196 & 16 & 43 \\
2015 & 181 & 204 & 10 & 35 \\
2016 & 162 & 212 & 12 & 37 \\
2017 & 148 & 216 & 7 & 43 \\
2018 & 134 & 235 & & 73 \\
\hline
\end{tabular}

Źródło: Opracowanie własne na podstawie danych vdp.

Dominacja hipotecznych listów zastawnych widoczna jest w nowych emisjach. W 2018 r. udział hipotecznych listów zastawnych w nowych emisjach listów wynosił

${ }^{46}$ Tamże. 
85,7\%. Natomiast udział publicznych listów zastawnych wyniósł 14,3\%. W 2018 roku nie było żadnych nowych emisji listów refinansujących kredyty na zakup statków i samolotów.

Tabela 2. Struktura emisji listów zastawnych w Niemczech (2018) w mld euro

\begin{tabular}{|l|c|c|}
\hline \multicolumn{1}{|c|}{ Wyszczególnienie } & Nowe emisje & Listy w obiegu \\
\hline Ogółem & 50,4 & 369,1 \\
Publiczne listy zastawne & 7,2 & 133,7 \\
Hipoteczne listy zastawne & 43,2 & 233,7 \\
Okrętowe listy zastawne & 0,0 & 1,2 \\
Samolotowe listy zastawne & 0,0 & 0,5 \\
\hline
\end{tabular}

Źródło: Fakten Geschäftzahlen der Pfandbriefbanken. Pfandbrief - und Kreditgeschäft 2018 im Überblick, vdp, Berlin 2019.

Ocena ryzyka listów zastawnych opiera się na ratingach międzynarodowych agencji ratingowych. Przeważająca część emisji objęta jest ratingiem. Na rynku są również emisje bez ratingu, ale ich udział wynosi poniżej 10 proc. i dotyczy niewielkich emisji ${ }^{47}$.

Relatywnie najlepiej rozwiniętą metodykę nadawania ocen ratingowych listom zastawnym mają międzynarodowe agencje ratingowe. Na rynku niemieckim własne metodyki ratingowe w zakresie listów zastawnych posiadają również mniejsze, lokalne instytucje ratingowe (np. Scope Ratings). Z obliczeń dokonanych na podstawie danych ESMA wynika, że możliwość nadawania ratingów listom zastawnym ma siedem agencji ratingowych zarejestrowanych na dzień 5.07.2019 r. w UE. Jednak najbardziej liczy się rating nadawany dłużnym papierom wartościowym przez jedną z trzech renomowanych amerykańskich agencji ratingowych: Standard\&Poor's (S\&P), Moody's, i Fitch. W przypadku większości dużych inwestorów instytucjonalnych rating odgrywa bardzo ważną rolę przy wyborze do swojego portfela papierów wartościowych, w które decydują się inwestować posiadane środki finansowe. Jak wynika z badań ankietowych przeprowadzonych przez agencję Fitch w 2012 roku, aż 94\% inwestorów instytucjonalnych uważało, że listy zastawne muszą posiadać rating od przynajmniej jednej znanej agencji ratingowej, aby można było w nie inwestować ${ }^{48}$. Formalnie wymóg ten wynika $\mathrm{z}$ rekomendacji organów nadzorczych i zapisów w statutach funduszy inwestycyjnych czy innych inwestorów instytucjonalnych. Niemiecki rynek listów zastawnych potwierdza, że w rozwoju ratingu podstawową rolę odgrywają uwarunkowania regulacyjne, które uniemożliwiają inwestowanie w papiery wartościowe bez ratingu.

$\mathrm{Na}$ rynku listów zastawnych $\mathrm{w}$ Niemczech mamy do czynienia $\mathrm{z}$ oligopolem w zakresie oceny standingu/ratingu tych papierów. Świadczą o tym następujące dane Verband deutscher Pfandbriefbanken w Berlinie (vdp): w latach 2011-2012 aż 211 programów emisji listów zastawnych posiadało rating nadany przez Moody’s, 126 programów dysponowało ratingiem od agencji Fitch, a 96 programów mogło się wykazać ratingiem od $\mathrm{S} \& \mathrm{P}^{49}$. Ratingi listów zastawnych innych agencji ratingowych (Scope Ratings) są nieliczne i często przybierają charakter tzw. ratingów

\footnotetext{
${ }^{47}$ Der deutsche Pfandbriefmarkt 2017/2018, op. cit., s. 17.

${ }^{48}$ M. Melms, op. cit., s. 65.

${ }^{49}$ Tamże, s. 65.
} 
niezamawianych (unsolicited rating), co wskazuje na trudności w przełamywaniu oligopolistycznej sytuacji przez mniejsze agencje ratingowe. Emitenci bowiem zlecają rating tym agencjom, które są uznawane przez inwestorów i wymienione w regulacjach.

Oceniając poziom ocen można stwierdzić, że niemieckie listy zastawne jako jedne $\mathrm{z}$ najbardziej bezpiecznych instrumentów finansowych na rynku kapitałowym cieszą się w Europie wysokim ratingiem. Większość emisji to listy zastawne oceniane na poziomie AAA lub AA.

Tablica 3. Rating listów zastawnych - struktura pod względem ocen w proc.

\begin{tabular}{|l|c|c|c|c|c|c|c|c|c|}
\hline \multirow{2}{*}{$\begin{array}{l}\text { Kategoria } \\
\text { ratingu }\end{array}$} & \multicolumn{3}{|c|}{2015 (IV kw.) } & \multicolumn{2}{c|}{2017 (II kw.) } & \multicolumn{3}{c|}{2018 (II kw.) } \\
\cline { 2 - 11 } & Moody's & S\&P & Fitch & Moody's & S\&P & Fitch & Moody's & S\&P & Fitch \\
\hline AAA & 78 & 89 & 87 & 73 & 80 & 91 & 74 & 80 & 86 \\
\hline AA- do AA+ & 18 & 0 & 13 & 23 & 10 & 9 & 21 & 10 & 14 \\
\hline A- do A+ & 3 & 11 & 0 & 3 & 10 & 0 & 3 & 10 & 0 \\
\hline $\begin{array}{l}\text { BBB do } \\
\text { BBB+ }\end{array}$ & 1 & 0 & 0 & 3 & 0 & 0 & 3 & 0 & 0 \\
\hline
\end{tabular}

Źródło: Opracowanie własne na podstawie danych z raportów: Der deutsche Pfandbriefmarkt 2018/2019, Eine Fachthemenreihe der DZ HYP | September 2018, s. 11; Der deutsche Pfandbriefmarkt 2016/2017, Eine Fachthemenreihe der DZ HYP | September 2017, s. 16.

Z informacji zawartych w tablicy 3. wynika, że w latach 2015-2018 oceny listów zastawnych były wysokie i kształtowały się w zdecydowanej większości co najmniej na poziomie podwójnego A. Z przeprowadzonych obliczeń wynika, że oceny na poziomie AAA miało w 2015 r. (średnia dla trzech największych agencji ratingowych) 84 proc. listów zastawnych, a w 2018 r. 80 proc. Tym samym agencje ratingowe potwierdzają podstawową charakterystykę listu zastawnego związaną $\mathrm{z}$ wysokim bezpieczeństwem (niskim ryzykiem) tych instrumentów finansowych. O wysokim bezpieczeństwie niemieckich listów zastawnych świadczy również fakt, że agencje praktycznie wszystkie emisje zaliczają do klasy inwestycyjnej, charakteryzującej się niskim ryzykiem inwestycyjnym.

Rating wykazuje również relatywnie dużą stabilność w czasie, nawet pomimo korekt w zakresie metodyki, które wystapiły w badanym okresie. Stabilność ratingów w czasie oznacza, że w badanym okresie nie wystapily istotne zmiany w kondycji emitentów i prawdopodobieństwie terminowości spłaty listów zastawnych. Trzeba jednak pamiętać, że agencje ratingowe preferują koncepcję ratingu „przez cykl” (Through-the-Cycle), w której zakłada się znalezienie balansu między aktualnością oceny ratingowej, a jej stabilnością ${ }^{50}$ W takim podejściu oceny ratingowe nie podlegają zmianom pod wpływem czynników krótkookresowych.

Wyniki przedstawione $\mathrm{w}$ tablicy 3. potwierdzają również powszechną opinię o konserwatyzmie Moody's w zakresie ocen ratingowych. W 2018 r. Moody's nadała rating na poziomie potrójnego A 74 proc. ocenianych emisji, natomiast Fitch, uchodzący za agencję ratingową nadającą $\mathrm{z}$ reguły lepsze oceny emitentom i emisjom, nadał najwyższą ocenę zdecydowanej większości ocenianych emisji (86 proc.). Emitenci wykorzystują przede wszystkim rating Moody’s. Jednak część programów listów

${ }^{50}$ E. I. Altman, H. A. Rijken, How rating agencies achieve rating stability, Journal of Banking\&Finance 28, 2004, s. 2681. 
zastawnych ma podwójny lub potrójny rating. Ten fakt podkreśla znaczenie ratingu jako czynnika rozwojowego niemieckiego rynku listów zastawnych.

\section{Zakończenie}

Rating stanowi nieodłączny element rynku listów zastawnych. Pomimo niskiego ryzyka inwestycyjnego i wysokich zabezpieczeń listów zastawnych, rating nadawany jest w praktyce wszystkim emisjom. Koszty związane z nadaniem ratingu ponoszą emitenci, jednak nie są one wysokie, biorąc pod uwagę, że rozkładają się na lata.

Metodyka nadawania ratingu listom zastawnym opiera się na kombinacji czynników ilościowych i jakościowych. W analizowanej metodyce Moody's na uwagę zasługuje podejście oparte na koncepcji straty oczekiwanej, co należy traktować w kategoriach zalety systemu ratingowego Moody's nad systemami innych agencji ratingowych. Przeprowadzona szczegółowa ocena metodyki Moody's wskazuje na jej ewolucję polegająca na zmniejszeniu się roli ratingu emitenta. Wpływ na to miały zmiany prawne wyłączające listy zastawne $\mathrm{z}$ postępowania bail-in. $\mathrm{Z}$ badań niemieckiego rynku listów zastawnych wynika, że rating jest stabilny $\mathrm{w}$ czasie, a nadawane oceny zawierają się głównie $\mathrm{w}$ przedziale AAA do AA, co świadczy o bardzo wysokim bezpieczeństwie niemieckich listów zastawnych. Koncentracja ocen w przedziale AAA do AA świadczy o tym, że rating spełnia na rynku głównie rolę instrumentu potwierdzającego wysoką jakość listów zastawnych

$\mathrm{Na}$ rynku ocen dominują największe agencje ratingowe, przy marginalnej roli mniejszych agencji ratingowych, co wskazuje na oligopolistyczną strukturę rynku i silne bariery wejścia na rynek. Przełamanie tej sytuacji w najbliższych latach na rynku niemieckim będzie bardzo trudne. Inwestorzy ufają bowiem przede wszystkim ocenom nadanym przez Moody's, Standard\&Poor's i Fitch.

\section{Literatura}

Altman E. I., Rijken H. A., 2004, How rating agencies achieve rating stability, Journal of Banking\&Finance 28.

Covered Bonds - Ratingmethoden erklärt: Moody’s, 2017, Research-Publikation der DZ Bank AG.

Der deutsche Pfandbriefmarkt 2017/2018, 2017. Deutsche Pfandbriefe im Trend der Zeit, Eine Fachthemenreihe der DZ HYP.

Der deutsche Pfandbriefmarkt 2018/2019. Deutsche Pfandbriefe unter Einfluss Europas, 2018, Eine Fachthemenreihe der DZ HYP.

Dżuryk A., List zastawny a stabilność polskiego system finansowego, Publikacja Europejskiego Kongresu Finansowego, Sopot, 2017.

Foster Y., Purwin V., 2011, Covered Bond Rating.

Golin J., Uncovering covered bonds [w:] J. Golin (red.), Covered Bonds beyond Pfnadbriefe. Innovations, Investment and Structured Alternatives, London.

J. Tolckmitt, O. Stôcker, 2017, Die rechtlichen Grundlagen der Pfandbriefemissionen, Der Pfandbrief 2017/2018, vdp, Berlin.

Kemmisch R., Wilkinson Ch., 2017, Covered Bonds in the European Union: Harmonisation of legal frameworks and market behaviours. Final report, European Commission.

Melms M., 2012, Vergleichende Darstellung der Ratingansätze für Pfandbriefe, 2012,

Norddeutsche Landesbank [w:] Der Pfandbrief 2012/2013, Verband deutscher Pfandbriefbanken, 
http://doczz.com.br/doc/1202195/der-pfandbrief-2012---2013---verband-deutscherpfandbrief...[dostęp: 10.01.2018].

R. Monro-Davis, 1996, Die Bonitätsbewertung von Banken, [w:] H. E. Büschgen, O. Everling, Handbuch Rating, Gabler, s. 216.

Moody's Approach to Rating Covered Bonds, 2019, Moody's Investors Service.

Pfandbrief-Arten,

https://www.pfandbrief.de/site/de/vdp/pfandbrief/pfandbrief_emissionen/pfandbrief_arten.html Scholz H., 1996, Bedeutung des Ratings für die Emission von Pfandbriefen [w:] H. E. Büschgen, O. Everling, Handbuch Rating, Gabler.

Schwarcz S. L., 2011, The Conundrum of Covered Bonds, The Business Lawyer, Vol. 66

Soldera J., Soriano J. P., Lindstrom N., Rating agencies and methodology. Moody's [w:] ECBC European Covered Bond Fact Book 2018, EMF/ECBC, 2018.

Soldera J., Soriano J. P., Lindstrom N., Rating agencies and methodology. Moody's [w:] ECBC European Covered Bond Fact Book 2019, EMF/ECBC, 2019.

Sprangler M., Werner R., 2014, German Covered Bonds. Overview and Risk Analysis of Pfandbriefe, Springer.

Vucetich A., Watson A., 2013, Discovering covered bonds - the market, the challenges, and the Reserve Bank's response, Reserve Bank of New Zealand: Bulletin, Vol. 76, No. 2.

\begin{abstract}
The ratings of global credit rating agencies play a special role in the covered bond market. Due to the high degree of complexity in the issuance of covered bonds in the vast majority of cases, an issue of covered bonds has a rating assigned by at least one credit rating agency. This means that the rating is an important determinant of the covered bond market. The main aim of the article was to examine the theoretical and practical elements related to the impact of ratings on the development of German covered bonds (Pfandbriefe). Our research confirms the thesis regarding the importance of the rating in the development of the German covered bond market. In the methodological aspect, credit rating is a combination of quantitative, qualitative and country risk elements. The research shows that the rating level of German mortgage bonds is high and, equally important, stable over time. Despite the high security of covered bonds, the rating of individual issues is awarded by two or three separate agencies, which determine the importance of the rating as a factor in the development of the market.
\end{abstract}

Key words: covered bond, rating, market analysis.

JEL Codes: G21, G23, G24.

Informacje o autorach:

Błażej Lepczyński, dr

Uniwersytet Gdański

Jana Bażyńskiego, 8, Gdańsk, Polska

e-mail: blazej.lepczynski@ug.edu.pl

ORCID: 0000-0002-1954-1144

Eugeniusz Gostomski, dr hab., prof. UG

Uniwersytet Gdański

Jana Bażyńskiego, 8, Gdańsk, Polska

e-mail: eugeniusz.gostomski@ug.edu.pl

ORCID: 0000-0003-0699-1928 